\title{
Cross-Country Interest Rate Trends. The Case of European Countries
}

\author{
Ülkelerarası Faiz Oranları Trendleri: Avrupa Ülkeleri Örneği \\ Emrah ARIOĞLU \\ Koray TUAN ${ }^{2}$
}

\begin{abstract}
In this study, we investigate the co-movements in interest rates for 16 European countries. For this purpose, we analyze the time series properties of short-term and long-term interest rates, both real and nominal. The evidence suggests that there is some degree of co-integration for the interest rates between European Countries. The number of countries that are co-integrated gets larger as we turn our attention from long-term interest rates to short-term interest rates. However, as we turn our attention from nominal interest rates to real interest rates the number of country pairs that are co-integrated gets smaller. When we investigate for common features, no common feature is found to exist between any of the country pairs investigated.
\end{abstract}

Keywords: Interest Rates, Co-movements, Co-integration, Common Features

\section{ÖZTT}

Bu çalışmada, 16 Avrupa ülkesinde faiz oranlarının birlikte hareketi incelemektedir. Bu amaçla real ve nominal bazda ksa ve uzun vadeli faiz oranlarının zaman serisi özellikleri incelenmektedir. Bulgulara göre; Avrupa ülkelerindeki faiz oranları arasında belli bir ölçüde kointegrasyon mevcuttur. Kısa vadeli faiz oranlarına kıyasla uzun vadeli faiz oranları söz konusu olduğunda, daha çok ülkede faiz oranları arasında kointegrasyon mevcuttur. Öte yandan, nominal faiz oranlarına kyyasla, real faiz oranları incelendiği zaman, daha az ülkede faiz oranlan arasında kointegrasyon olduğu görülmektedir. Faiz oranlarının ortak özellikleri incelendiğ zaman ise, incelenen ülke çiftlerinin hiç birisinde ortak özellikler olduğu belirlenememiştir.

Anahtar Kelimeler: Faiz Oranları, Birlikte Hareket, Kointegrasyon, Ortak Özellikler

\footnotetext{
${ }^{1}$ Araş.Gör., Drexel University Department of Finance, ea97@ drexel.edu

${ }^{2}$ Araş.Gör., Q̧ukurova Üniversitesi, i.i.i.B.F., İşletme Bölümü, ktuan@ @u.edu.tr
} 


\section{INTRODUCTION}

Since financial liberalization has resulted in the lessening of capital controls and motivated the flow of capital across national boundaries, interest rate linkages among economies around the would be expected to be strengthening at an increasing pace (Devine, 1997).

There are various studies in the literature investigating the cross-country interest rate linkages. DeGrauwe (1989) examines the interdependence of short-term interest rates and long-term interest rates for EMS, and his findings suggest that there is little evidence of any EMS interest rate having substantial explanatory power over the other countries' rates. Throop (1994) examines the links between interest rates across countries, including USA, Canada, Germany and Japan. He investigates the existence of co-integrating relationships between USA and various countries by applying Johansen co-integration procedure. In terms of short-term interest rates, his evidence suggests that there is no significant relationship suggesting co-integration. In terms of long-term interest rates, he only finds evidence of co-integration between USA and Germany.

Kirchgassner and Wolters (1995) examine the short-term interest rate linkages between Germany and other EMS countries by applying granger causality tests and cointegration analysis. Their provide evidence in favor of the existence of level relationships between interest rates. Bremnes et al. (1997) investigate the multivariate co-integration structure among interest rates for US, UK, France, Japan and Germany in the euro-currency markets. Their findings suggest that these interest rates can be modeled as a multivariate co-integrating system, and the number of co-integration vectors increase over time.

Thornton and García-Herrero (1997), examine the interest rate and monetary base linkages within EMS. Their evidence suggests that there is a long-run relationship between German and other EMS interest rates. In addition the bivariate VAR analysis suggest that there is granger causality in terms of interest rates stemming from either German to other European markets or it is bidirectional. In another study by Zhou (2003), the bivariate long run relationships between interest rates within the EMS are investigated. Zhou suggests that the rejection of the long run relationship by some earlier studies might be due to under specification of deterministic variables used in the models. In this study, Zhou uses Johansen co-integration tests for Germany and other four EMS interest rate pairs and the results suggest that over time interest rates of EMS countries start moving together more closely.

Poghosyan and de Haan (2007) investigate the interest rate linkages for selected European countries. They use the rolling threshold vector error correction models. There evidence suggests that there are decreasing thresholds over time for specific country pairs, and the interest rate linkages across countries is getting stronger in time. Lindenberg and Westermann (2009) examine the co-movements of interest rates across G-7 countries. They analyze the time series characteristics of interest rates and test for the common features valid across countries. They apply co-integration, serial correlation common feature and codependence tests, by using both nominal and real interest rates. They find little evidence of co-movement across countries. In addition 
their evidence suggests that most of the interest rates are not co-integrated and there are only a few cases of common cycles.

In this study, we investigate the co-movements in interest rates for 16 European countries. For this purpose, we analyze the time series properties of short-term and long-term interest rates, both real and nominal. For interest rates, which are suggested to be non stationary by the empirical evidence, we apply Engle and Granger co-integration procedure in order to investigate for common trends. For stationary interest rates, we test for common cycles applying serial correlation common feature test.

The evidence suggests that there is some degree of co-integration of the interest rates between European Countries. The number of countries which are suggested to be cointegrated is larger for short-term interest rates (both real and nominal) as opposed to long-term interest rates. Also, the number of countries that are co-integrated is smaller in terms of real interest rates (both short-term and long-term) compared to nominal interest rates. These findings suggest that the level of co-integration in terms of interest rates, are substantially higher in European countries, compared to G-7 countries shown by Lindenberg and Westermann (2009). This might be the consequence of geographical closeness.

When we investigate for common features by applying the serial correlation common feature test, the evidence suggests that a common feature does not exist between any of the country pairs studied in this analysis.

\section{DATA AND SAMPLE}

We conduct this study by using nominal and ex post real interest rates for the following European countries: Austria, Belgium, Denmark, Finland, France, Germany, Holland, Iceland, Ireland, Italy, Norway, Portugal, Spain, Sweden, Switzerland and UK. These countries are selected based on data availability among all the European countries, in order to have an economically meaningful analysis of time series data. We use the short-term (3 months) interest rates and long-term (10 years) interest rates, following many of the previous studies mentioned earlier. The data is gathered from OECD's web site. In order to convert the nominal interest rates into ex post real interest rates, we use CPI index gathered from IMF's International Financial Statistics web site. All the data is quarterly and the sample period covers 1956-2009, again selected based on data availability.

The graphs of the interest rates, both nominal and ex post real, and both short-term and long-term are presented through Figure 1 and Figure 4. By investigating the graphs visually, we can see that the interest rates, especially in the later time period, probably due to the changes after the formation of the European Union, move closely. Especially this pattern is significantly observable for the ex post real interest rates.

This is an expected result since we expect stronger linkages among international real rates than nominal rates, due to the Fisher-Open Condition. This condition basically states that expected real rates of interest should be equal in different countries because investors would want to invest their funds in countries which have the highest return rates (Devine, 1997). 


\section{PRELIMINARY ANALYSIS}

In this section, we analyze the lag structure of interest rates; nominal and real, shortterm and long-term interest rates. We first perform the unit root tests using Augmented Dickey-Fuller (ADF) tests. The general representation for ADF tests is:

$\Delta \mathrm{x}_{\mathrm{t}}=\mu+\beta \mathrm{t}+\gamma \mathrm{x}_{\mathrm{t}-1}+\sum \quad \varphi_{\mathrm{j}} \Delta \mathrm{x}_{\mathrm{t}-\mathrm{j}}+\varepsilon_{\mathrm{t}}$

In (1)," $\Delta$ " represents the first difference operator and " $t$ " represents a time trend. The ADF tests are performed for 2 different cases: with a constant, with a constant and a trend. The t-statistics of the ADF tests are compared with the MacKinnon (1996) critical values and only the P-values associated with the t-statistics are presented in Table I through Table IV. We apply the ADF tests for both the levels and the first differences of the time series data.

Evidence in Table I suggests that, for long-term nominal interest rates, the null hypothesis of a unit root cannot be rejected in levels and the null hypothesis of a unit root is rejected in first differences for all of the 16 countries. In other words, the $\mathrm{I}(\mathrm{d})$ structures for the 16 countries' long-term nominal interest rates are I(1). When we look at Table II, we can observe that for long-term real interest rates, the null hypothesis of a unit root cannot be rejected in levels, except for Austria, Italy and UK. In addition, the null hypothesis of a unit root is rejected in first differences for all of the 16 countries. In other words, the I(d) structures for the 13 countries' long-term real interest rates, except for Austria, Italy and UK are I(1).

On the other hand, evidence in Table III suggests that, for short-term nominal interest rates, the null hypothesis of a unit root cannot be rejected in levels, except for Germany, Holland and Switzerland. The null hypothesis of a unit root is rejected in first differences for all of the 16 countries. In other words, the $I(d)$ structures for the 13 countries' long-term real interest rates, except for Germany, Holland and Switzerland are I(1). When we look at Table IV, for short-term real interest rates, the null hypothesis of a unit root cannot be rejected in levels, except for Belgium, Holland, Spain, Switzerland and UK. The null hypothesis of a unit root is rejected in first differences for all of the 16 countries. In other words, the I(d) structures for the 11 countries' long-term real interest rates, except for Belgium, Holland, Spain, Switzerland and UK are I(1).

Secondly, we analyze the lag structure of the time series data. We estimate the AR structures of each of the series using the following regression:

$\mathrm{x}_{\mathrm{t}}=\mu+\sum \quad \beta_{\mathrm{i}} \mathrm{x}_{\mathrm{t}-\mathrm{i}}+\varepsilon_{\mathrm{t}}$

We perform the analysis for levels for the interest rates and since most are nonstationary, as suggested by the evidence in Tables I through IV, we also perform the analysis with the first differences of the interest rates and report the results in Table V.

When we look at Table V, we see that the lag structures of all interest rates investigated vary. For the long-term nominal interest rates, it is observed that the majority of the countries have and $\operatorname{AR}(1)$ structure, and also $\mathrm{AR}(2), \operatorname{AR}(4)$ and $\mathrm{AR}(5)$ are the following most common $\mathrm{AR}(\mathrm{p})$ structures. For the long-term real interest rates, it is observed that 
most common structures are $\mathrm{AR}(1)$ and $\mathrm{AR}(4)$, followed by $\mathrm{AR}(2), \mathrm{AR}(5)$ and $\mathrm{AR}(8)$. For the short-term nominal interest rates, the most common $\operatorname{AR}(\mathrm{p})$ structures are $\operatorname{AR}(1)$, followed by $\operatorname{AR}(2)$. Lastly, for the short-term real interest rates, the most common $\operatorname{AR}(p)$ structures are $\operatorname{AR}(1), \operatorname{AR}(2), \operatorname{AR}(4)$ and $A R(5)$.

\section{CO-MOVEMENTS OF INTEREST RATES AMONG EUROPEAN COUNTRIES}

In this section, the analysis is conducted in 2 parts: for interest rates which are non stationary in the levels and stationary in the first differences, in other words, which have I(1) structure, we perform Engle and Granger co-integration tests. For interest rates, which are stationary in the levels, we perform serial common feature and codependence tests, if possible at all.

We first analyze the interest rate series which are non stationary by applying Engle and Granger co-integration methodology. The first step is to test the variables for their integration order. For co-integration to exist, we need the variables to be integrated of the same degree. To determine the number of unit roots in each variables, we can use tests such as Dickey-Fuller test (DF test), augmented Dickey-Fuller test (ADF test), Phillips-Perron test, and some other tests as well. After applying these tests, if the results show that the variables are stationary, we do not need to proceed since standard time series models can be applied to stationary variables.

In the second step, we estimate the long run relationship between the variables. If the results from the previous step state that both variables are $\mathrm{I}(1)$, we then estimate the long run equilibrium relationship in the form as:

$\mathrm{X}_{\mathrm{t}}^{\mathrm{k}}=\beta_{0}+\beta_{1} \mathrm{X}_{\mathrm{t}}^{\mathrm{m}}+\mathrm{e}_{\mathrm{t}}$

To check whether the variables are co-integrated, we first denote the residuals from equation (3) as "ê". If we find the deviations from long run equilibrium are stationary, then we can conclude that our series are co-integrated.

For co-integration tests, we perform the test first with the nominal long-term interest rates. As mentioned earlier before, no one of the nominal long-term series are stationary. Thus we perform the bivariate co-integration analysis for all of the 16 countries' pairs. ADF test probabilities of the relevant residuals, which are required to determine the $\mathrm{I}(\mathrm{d})$ structure of the residuals, are presented in Table VI. When we look at the Table, we observe the co-integration relationship between various country pairs, in terms of long-term nominal interest rates.

The Table might need some further explanation due to the limited space available in the Table. Observing the Table vertically, we see that the countries, to whom the dependent variables belong to, are listed in the first column. The dependent variable just mentioned corresponds to $\mathrm{X}_{\mathrm{t}}^{\mathrm{k}}$ in equation (3). For example when the long-term nominal interest rates for Austria are denoted by $\mathrm{X}_{\mathrm{t}}^{\mathrm{k}}$ in equation (3), and the long-term nominal interest rates for Belgium are denoted by $\mathrm{X}_{\mathrm{t}}^{\mathrm{m}}$ in equation (3), the p-value (probability) for the $\mathrm{ADF}$ test regarding the residual derived from the long-run relationship presented in equation (3) between the two series is 0.0003 . This significant $p$-value suggests that the 
residual from the long-run relationship between the long-term nominal interest rates of Austria and Belgium is $\mathrm{I}(0)$ at $5 \%$ level. This result, considered in addition to the previous finding that both of the long-term nominal interest rates for Austria and Belgium were I(1), suggests that the two series are co-integrated. When we look at the table the other way around, this time if the long-term nominal interest rates for Belgium are denoted by $\mathrm{X}_{\mathrm{t}}^{\mathrm{k}}$ in equation (3), and the long-term nominal interest rates for Austria are denoted by $\mathrm{X}_{\mathrm{t}}^{\mathrm{m}}$ in equation (3), the $\mathrm{p}$-value is 0.0001 this time, suggesting the same co-integration evidence. This two-way evidence is valid for all country pairs except some special cases, which are explained in a couple of paragraphs.

What we observe in Table VI is that Austria seems to be co-integrated with 8 , Belgium with 7 , Denmark with 11 , Finland with 8 , France with 8 , Germany with 4 , Holland with 5 , Iceland with 3 , Ireland with 5 , Italy with 6 , Norway with 3 , Portugal with 7 , Spain with 8 , Sweden with 12 , Switzerland with 8 and finally UK with 7 countries, in terms of long-term nominal interest rates out of 15 possible countries to be co-integrated with. The finding about Germany having co-integration with so few countries is very interesting, when considered in light of previous evidences about Germany Dominance theory, which is widely mentioned in the literature. Further evidence in the paper, regarding other interest rate series will be of interest when investigating this situation.

As mentioned previously, there are couple special cases, worth paying attention to. When we look at Table VI, we see that when Iceland's long-term nominal interest rate is the independent variable in the bivariate long run relationships, the ADF test statistic for the residuals suggests that no country is co-integrated with Iceland. However, when Iceland's long-term nominal interest rate is the dependent variables in the bivariate long run relationship, the ADF test statistic probabilities for the residuals are all around $5 \%$ suggesting that most countries are co-integrated with Iceland. This is in contrast with the evidence just mentioned. This contradiction might be due to the fact that, when we decided whether the long-term interest rate series for Iceland were stationary or not, even though we could suggest that the series was $\mathrm{I}(1)$ for $5 \%$ significance level, it was $\mathrm{I}(0)$ at $10 \%$ level when tested with the model including an intercept. And for cointegration to exist in Engle-Granger sense, we need the series to be $\mathrm{I}(1)$. Thus the results for Iceland should be considered with caution. A similar problem in terms of cointegration and stationary of series is valid for Ireland and Sweden and Spain series as well.

Secondly, we perform the test with the real long-term interest rates. For real long-term nominal interest rates, Austria, Italy and UK were found to be $\mathrm{I}(0)$ previously. Thus, we perform the bivariate co-integration analysis for all of the countries' pairs, except these 3. ADF test probabilities of the relevant residuals derived from the bivariate long run relationship regressions of country pairs' for long-term real interest rates are presented in Table VII.

What is observed in Table VII is that Belgium is co-integrated with 6, Denmark with 4, Finland with 2, France with 5, Germany with 3, Holland with 2, Iceland with 2, Ireland with 2, Norway with 5, Portugal with no, Spain with 3, Sweden with 4, Switzerland with 10 countries, in terms of long-term real interest rates out of 12 possible countries to be co-integrated with. 
Again for real long-term interest rates, there are couple special cases, worth paying attention to. When we look at Table VII, we see the same problem is valid for France, Holland, Denmark, Norway and Switzerland. Again, these are the only countries which had mixed evidence in terms of stationary. Thus the results should be considered with caution. However, the same problem is valid for Ireland, as well, which was suggested to be I(1) by previous evidence in the study. Therefore, it needs further investigation. When we examine the stationary structure for the real long-term interest rates of Ireland, this time using the ADF test with no intercept nor trend, the series turn out to be $\mathrm{I}(0)$, and as mentioned earlier, to derive healthy results, we need both series in the cointegration analysis to be $\mathrm{I}(1)$. This might explain the potential contradicting results for Ireland in this part of the analysis.

Also one interesting point is that as we turn our attention from nominal to real for longterm interest rates, we see that the number of countries that each country is cointegrated with decreases substantially. The same issue will be investigated for the short-term interest rates, as well.

Thirdly, the test is performed with the nominal short-term interest rates. For nominal short-term nominal interest rates, there were 3 countries found to be $\mathrm{I}(0)$ previously: Germany, Holland and Switzerland. Therefore the bivariate co-integration analysis is performed for all of the countries' pairs, except these 3. ADF test probabilities of the relevant residuals derived from the bivariate long run relationship regressions of country pairs' for nominal short-term interest rates are presented in Table VIII.

In Table VIII, we observe that Austria is co-integrated with 6, Belgium with 9, Denmark with 10, Finland with 7, France with 11, Iceland with 11, Ireland with 6, Italy with 6 , Norway with 7 , Portugal with 7 , Spain with 10 , Sweden with 8 , Uk with 7 countries, in terms of short-term nominal interest rates out of 12 possible countries to be co-integrated with.

Again for nominal short-term interest rates, there are couple special cases, we should pay attention to. When we look at Table VIII, we see the same problem is valid for Norway, Iceland and Spain. Thus the results should be considered with caution.

For the co-integration analysis, the last data series we consider is the real short-term nominal interest rates. For nominal short-term nominal interest rates, there were 5 countries found to be $\mathrm{I}(0)$ by previous findings: Belgium, Holland, Spain, Switzerland, UK. Thus we perform the bivariate co-integration analysis for all of the countries' pairs, except these 5, leaving us with 11 countries to investigate. ADF test probabilities of the relevant residuals derived from the bivariate long run relationship regressions of country pairs' for real short-term interest rates are presented in Table IX.

Table IX provides evidence suggesting that Austria is co-integrated with 4, Denmark with 7, Finland with 4, France with 9, Germany with 4, Iceland with 8, Ireland with 6 , Italy with 3 , Norway with 8, Portugal with 5 and Sweden with 4 countries, in terms of short-term nominal interest rates out of 10 possible countries to be co-integrated with.

Also, again, as we turn our attention from nominal to real for short-term interest rates, just like for the long-term interest rates, we see that the number of countries that each country is co-integrated with decreases substantially. 
This time for nominal short-term interest rates, there is only 1 special case, we should pay attention to, and it is Portugal. Thus the results for Portugal should be considered with caution.

To sum up, we can say that we observe some degree of co-integration for the interest rates between European Countries and the number of countries which are co-integrated gets larger as we turn our attention from long-term interest rates (both real and nominal) to short-term interest rates (again both real and nominal). Also, as we turn our attention from nominal interest rates (both short-term and long-term) to real interest rates (both short-term and long-term), the number of country pairs which are co-integrated gets smaller. These findings suggest that the levels of co-integration in terms of interest rates are substantially higher in European countries, compared to G-7 countries shown by Lindenberg and Westermann (2009).

\section{COMMON CYCLES AMONG THE EUROPEAN COUNTRIES}

In this last empirical section of the study, we apply the serial correlation common feature test among European countries' interest rate series. This test, developed by Engle and Kozicki (1993), can be viewed as a generalization of the co-integration tests (Lindenberg and Westermann, 2009). This test, contrary to the co-integration tests, can be meaningfully applied to stationary series. Thus, we apply this test for interest rate series which were suggested to be stationary by previous evidence. In addition, to be able to apply this test, the AR structure in the series should also be identical. Interest rate series, which are both stationary and have the same AR structure are very rare. For long-term real interest rates, we can apply this test to Austria and UK only, whereas for short-term nominal interest rates we can apply the test to Germany and Switzerland and lastly, for short-term real interest rates, we can apply the test to Belgium and Holland. For these 3 country pairs, we estimate the following:

$X_{t}^{k}=c+\beta X_{t}^{m}+e_{t}$

By two stage least squares method where the instrument variables are lagged values of $\mathrm{x}$ and $y$. In the second step of this analysis, we test to check if the residuals estimated from the regression above are driven by the same stochastic process. Thus, we estimate:

$\varepsilon_{\mathrm{t}}=\mathrm{c}+\sum \quad \zeta_{\mathrm{r}} \mathrm{X}_{\mathrm{t}-\mathrm{r}}^{\mathrm{k}}+\sum \quad \lambda_{\mathrm{r}} \mathrm{X}_{\mathrm{t}-\mathrm{r}}^{\mathrm{m}}+\mathrm{u}_{\mathrm{t}}$

By simple OLS, we estimate the regression above and next test the null hypothesis that all the lagged variables do not jointly explain the endogenous variable. If the null hypothesis cannot be rejected, then the pattern in the interest rates across country pairs is removed.

The results of this test are reported in Table X. Our candidates for the existence of a common feature for long-term real interest rates was Austria and UK, for short-term nominal interest rates was Germany and Switzerland and lastly for short-term real interest rate was Belgium and Holland. In this Table, we can observe that all the F statistics are greater than the critical $\mathrm{F}$ values at $5 \%$ level, thus we can reject the null hypothesis that a common feature exists between any of these country pairs given in Table X. 


\section{CONCLUSION}

In earlier studies, applying different econometric methods, there is mixed evidence regarding the existence of co-integration between European countries in terms of interest rates. After the introduction of the Euro, the evidence supporting the existence of co-integration gets larger. Studies conducted after the introduction of Euro; mostly, apply Johansen co-integration and rolling threshold vector error correction methodologies. In this study, we investigate the co-movements in interest rates for 16 European countries, by applying Engle and Granger co-integration procedure in order to investigate for common trends. In addition, for interest rates, which are suggested to be stationary by the analysis, we test for common cycles applying serial correlation common feature test.

The evidence in this study suggests that there is some degree of co-integration for the interest rates between European Countries and the number of countries which are suggested to be co-integrated gets larger as we turn our attention from long-term interest rates (both real and nominal) to short-term interest rates (again both real and nominal). Also, as we turn our attention from nominal interest rates (both short-term and longterm) to real interest rates (both short-term and long-term), the number of country pairs which are suggested to be co-integrated by the evidence just presented gets smaller. These findings suggest that the level of co-integration in terms of interest rates is substantially higher in European countries, compared to G-7 countries shown by Lindenberg and Westermann (2009). This might be the consequence of geographical closeness.

When we investigate for common features by applying the serial correlation common feature test, the evidence suggests that a common feature does not exist between any of the country pairs used in this analysis. However, the findings of this part should be observed with caution since we had a limited number of observations to be used for the serial correlation common feature test. 


\section{TABLES AND FIGURES}

Figure 1: Long-Term Nominal Interest Rates.

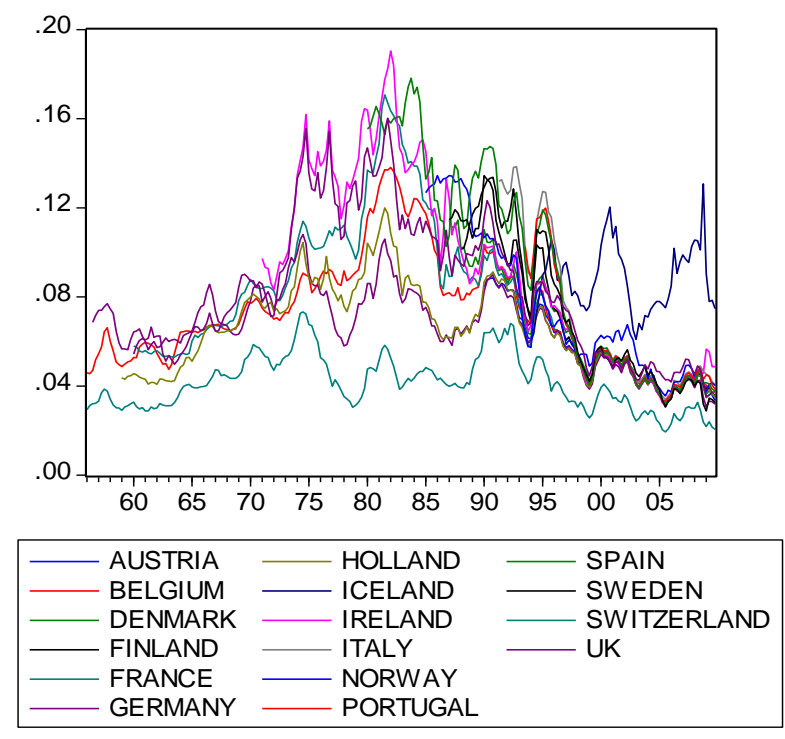

Figure 2: Long-Term Ex Post Real Interest Rates.

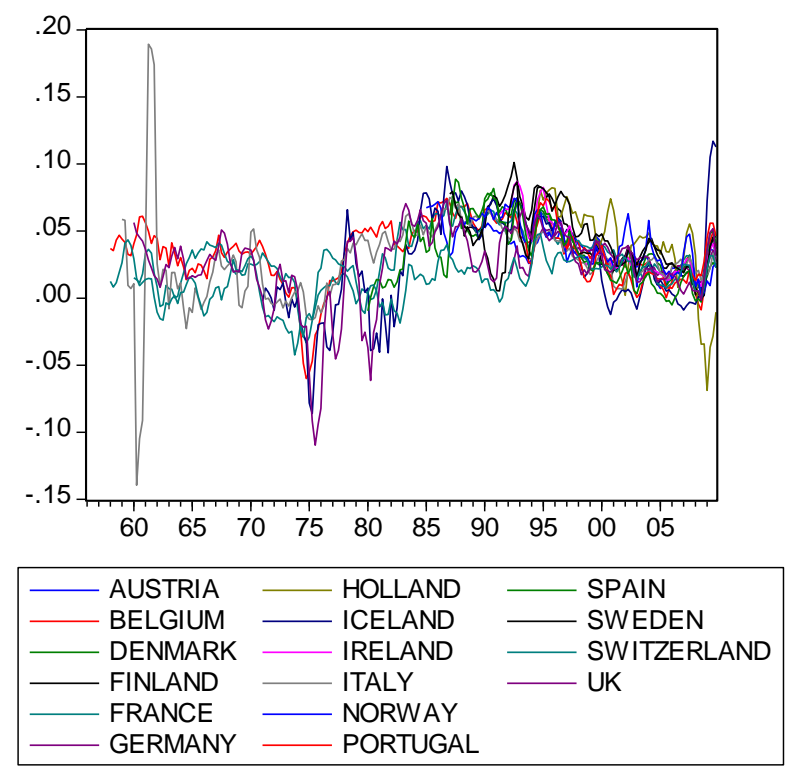


Figure 3: Short-Term Nominal Interest Rates.

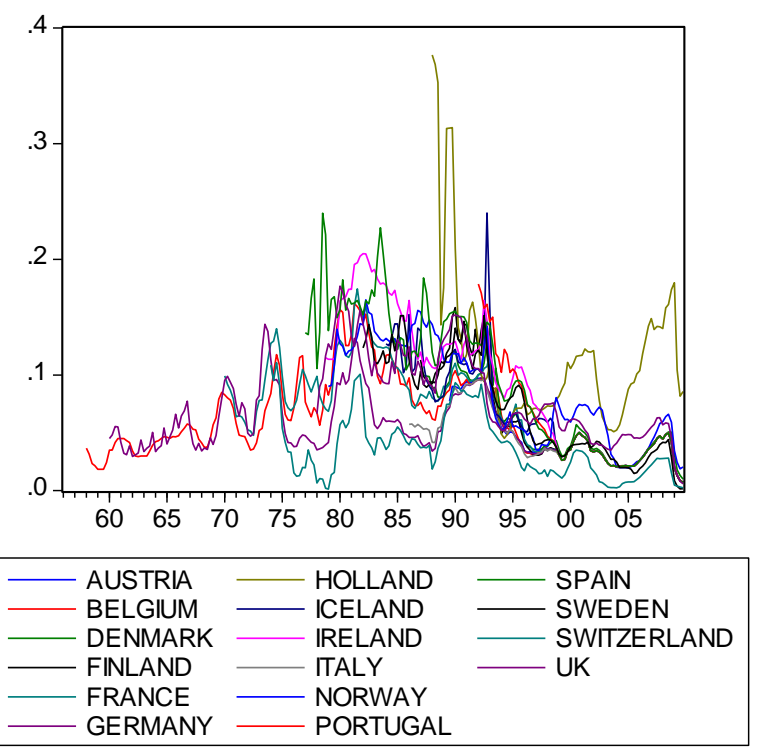

Figure 4: Short-Term Ex Post Real Interest Rates.

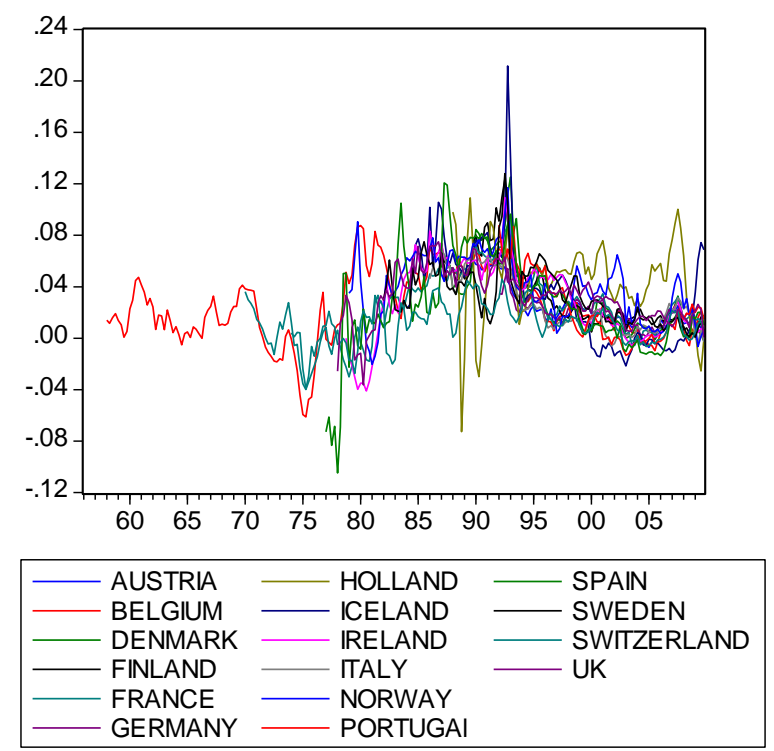


Table I: ADF Unit Root Test Results And I(d) Structures Of Long-Term Nominal Interest Rates.

\begin{tabular}{|c|c|c|c|c|c|}
\hline & \multicolumn{2}{|c|}{$\begin{array}{c}\text { ADF Test (Probabilities) } \\
\text { with levels }\end{array}$} & \multicolumn{2}{|c|}{$\begin{array}{l}\text { ADF Test (Probabilities) } \\
\text { with } 1^{\text {st }} \text { Differences }\end{array}$} & \multirow{2}{*}{$\begin{array}{c}\text { I(d) } \\
\text { Structures }\end{array}$} \\
\hline & $\begin{array}{c}\text { with } \\
\text { intercept }\end{array}$ & $\begin{array}{l}\text { with intercept } \\
\text { and trend }\end{array}$ & $\begin{array}{c}\text { with } \\
\text { intercept }\end{array}$ & $\begin{array}{l}\text { with intercept } \\
\text { and trend }\end{array}$ & \\
\hline Austria & 0.4154 & 0.1296 & $0.0000^{*}$ & $0.0000 *$ & $\mathrm{I}(1)$ \\
\hline Belgium & 0.5583 & 0.7468 & $0.0000 *$ & $0.0000 *$ & $\mathrm{I}(1)$ \\
\hline Denmark & 0.6851 & $0.0662 * *$ & $0.0000 *$ & $0.0000 *$ & $\mathrm{I}(1)$ \\
\hline Finland & 0.7295 & 0.1231 & $0.0000 *$ & $0.0000 *$ & $\mathrm{I}(1)$ \\
\hline France & 0.6833 & 0.7661 & $0.0000 *$ & $0.0000 *$ & $\mathrm{I}(1)$ \\
\hline Germany & 0.2923 & 0.2434 & $0.0000 *$ & $0.0000 *$ & $\mathrm{I}(1)$ \\
\hline Holland & 0.3492 & 0.4452 & $0.0000 *$ & $0.0000 *$ & $\mathrm{I}(1)$ \\
\hline Iceland & $0.0644 * *$ & 0.2575 & $0.0000 *$ & $0.0000 *$ & $\mathrm{I}(1)$ \\
\hline Ireland & 0.6961 & $0.0821 * *$ & $0.0000 *$ & $0.0000 *$ & $\mathrm{I}(1)$ \\
\hline Italy & 0.2758 & 0.3666 & $0.0038 *$ & $0.0048 *$ & $\mathrm{I}(1)$ \\
\hline Norway & 0.5443 & 0.3366 & $0.0000 *$ & $0.0000 *$ & $\mathrm{I}(1)$ \\
\hline Portugal & 0.4420 & 0.9048 & $0.0001 *$ & $0.0008 *$ & $\mathrm{I}(1)$ \\
\hline Spain & 0.6949 & $0.0368 *$ & $0.0000 *$ & $0.0000 *$ & $\mathrm{I}(1)$ \\
\hline Sweden & 0.7745 & $0.0314 *$ & $0.0000 *$ & $0.0000 *$ & $\mathrm{I}(1)$ \\
\hline Switzerland & 0.1087 & 0.2215 & $0.0000 *$ & $0.0000 *$ & $\mathrm{I}(1)$ \\
\hline UK & 0.7282 & 0.7782 & $0.0000 *$ & $0.0000 *$ & $\mathrm{I}(1)$ \\
\hline
\end{tabular}

Reported figures are the MacKinnon (1996) critical values. * implies significance at 5 $\%$ levels. ** implies significance at $10 \%$ levels.

Table II: ADF Unit Root Test Results And I(d) Structures Of Long-Term Real Interest Rates.

\begin{tabular}{|c|c|c|c|c|c|}
\hline & \multicolumn{2}{|c|}{$\begin{array}{c}\text { ADF Test (Probabilities) } \\
\text { with levels }\end{array}$} & \multicolumn{2}{|c|}{$\begin{array}{l}\text { ADF Test (Probabilities) } \\
\text { with } 1^{\text {st }} \text { Differences }\end{array}$} & \multirow{2}{*}{$\begin{array}{c}\text { I(d) } \\
\text { Structures }\end{array}$} \\
\hline & $\begin{array}{c}\text { with } \\
\text { intercept }\end{array}$ & $\begin{array}{l}\text { with intercept } \\
\text { and trend }\end{array}$ & $\begin{array}{c}\text { with } \\
\text { intercept }\end{array}$ & $\begin{array}{l}\text { with intercept } \\
\text { and trend }\end{array}$ & \\
\hline Austria & $0.0960 * *$ & $0.0296^{*}$ & $0.0000 *$ & $0.0000 *$ & $\mathrm{I}(0)$ \\
\hline Belgium & 0.3076 & 0.6252 & $0.0000 *$ & $0.0000 *$ & $\mathrm{I}(1)$ \\
\hline Denmark & 0.2215 & $0.0414 *$ & $0.0000 *$ & $0.0000 *$ & $\mathrm{I}(1)$ \\
\hline Finland & 0.3575 & 0.1381 & $0.0000 *$ & $0.0000 *$ & $\mathrm{I}(1)$ \\
\hline France & $0.0316^{*}$ & 0.1048 & $0.0000 *$ & $0.0000 *$ & $\mathrm{I}(1)$ \\
\hline Germany & 0.2441 & 0.2297 & $0.0000 *$ & $0.0000 *$ & $\mathrm{I}(1)$ \\
\hline Holland & 0.8598 & $0.0046 *$ & $0.0000 *$ & $0.0000 *$ & $\mathrm{I}(1)$ \\
\hline Iceland & 0.2629 & 0.4559 & $0.0000 *$ & $0.0003 *$ & $\mathrm{I}(1)$ \\
\hline Ireland & 0.5362 & 0.9691 & $0.0000 *$ & $0.0000 *$ & $\mathrm{I}(1)$ \\
\hline Italy & $0.0000 *$ & $0.0001 *$ & $0.0000 *$ & $0.0000 *$ & $\mathrm{I}(0)$ \\
\hline Norway & 0.4416 & $0.0988 * *$ & $0.0000 *$ & $0.0000 *$ & $\mathrm{I}(1)$ \\
\hline Portugal & 0.2856 & 0.9582 & $0.0000 *$ & $0.0000 *$ & $\mathrm{I}(1)$ \\
\hline Spain & 0.3881 & 0.3291 & $0.0000 *$ & $0.0000 *$ & $\mathrm{I}(1)$ \\
\hline Sweden & 0.3993 & 0.5832 & $0.0000 *$ & $0.0000 *$ & $\mathrm{I}(1)$ \\
\hline Switzerland & $0.0730 * *$ & 0.1036 & $0.0000 *$ & $0.0000 *$ & $\mathrm{I}(1)$ \\
\hline UK & $0.0002 *$ & $0.0010 *$ & $0.0000 *$ & $0.0000 *$ & $\mathrm{I}(0)$ \\
\hline
\end{tabular}

Reported figures are the MacKinnon (1996) critical values. * implies significance at 5 $\%$ levels. ** implies significance at $10 \%$ levels. 
Table III: ADF Unit Root Test Results And I(d) Structures Of Short-Term Nominal Interest Rates.

\begin{tabular}{|c|c|c|c|c|c|}
\hline & \multicolumn{2}{|c|}{$\begin{array}{c}\text { ADF Test (Probabilities) } \\
\text { with levels }\end{array}$} & \multicolumn{2}{|c|}{$\begin{array}{l}\text { ADF Test (Probabilities) } \\
\text { with } 1^{\text {st }} \text { Differences }\end{array}$} & \multirow{2}{*}{$\begin{array}{c}\text { I(d) } \\
\text { Structures }\end{array}$} \\
\hline & $\begin{array}{c}\text { with } \\
\text { intercept }\end{array}$ & $\begin{array}{l}\text { with intercept } \\
\text { and trend }\end{array}$ & $\begin{array}{c}\text { with } \\
\text { intercept }\end{array}$ & $\begin{array}{l}\text { with intercept } \\
\text { and trend }\end{array}$ & \\
\hline Austria & 0.3089 & 0.3704 & $0.0000^{*}$ & $0.0001 *$ & $\mathrm{I}(1)$ \\
\hline Belgium & 0.1075 & 0.2589 & $0.0000 *$ & $0.0000 *$ & $\mathrm{I}(1)$ \\
\hline Denmark & 0.6010 & 0.4380 & $0.0000 *$ & $0.0000 *$ & $\mathrm{I}(1)$ \\
\hline Finland & 0.7174 & 0.3741 & $0.0005 *$ & $0.0000 *$ & $\mathrm{I}(1)$ \\
\hline France & 0.3460 & 0.1057 & $0.0000 *$ & $0.0000 *$ & $\mathrm{I}(1)$ \\
\hline Germany & $0.0284 *$ & $0.0355 *$ & $0.0000 *$ & $0.0000 *$ & $\mathrm{I}(0)$ \\
\hline Holland & $0.0004 *$ & $0.0049 *$ & $0.0000 *$ & $0.0000 *$ & $\mathrm{I}(0)$ \\
\hline Iceland & 0.4018 & $0.0479 *$ & $0.0000 *$ & $0.0000 *$ & $\mathrm{I}(1)$ \\
\hline Ireland & 0.9322 & $0.0207 *$ & $0.0000 *$ & $0.0000 *$ & $\mathrm{I}(1)$ \\
\hline Italy & 0.6046 & 0.3661 & $0.0000 *$ & $0.0000 *$ & $\mathrm{I}(1)$ \\
\hline Norway & 0.6877 & $0.0190 *$ & $0.0000 *$ & $0.0000 *$ & $\mathrm{I}(1)$ \\
\hline Portugal & $0.0162 *$ & 0.1608 & $0.0000 *$ & $0.0000 *$ & $\mathrm{I}(1)$ \\
\hline Spain & 0.4873 & $0.0002 *$ & $0.0000 *$ & $0.0000 *$ & $\mathrm{I}(1)$ \\
\hline Sweden & 0.7806 & $0.0890 * *$ & $0.0000 *$ & $0.0000 *$ & $\mathrm{I}(1)$ \\
\hline Switzerland & $0.0371 *$ & $0.0813 * *$ & $0.0000 *$ & $0.0000 *$ & $\mathrm{I}(0)$ \\
\hline UK & 0.8519 & $0.0374 *$ & $0.0000 *$ & $0.0000 *$ & $\mathrm{I}(1)$ \\
\hline
\end{tabular}

Reported figures are the MacKinnon (1996) critical values. * implies significance at 5 $\%$ levels. ** implies significance at $10 \%$ levels.

Table IV: ADF Unit Root Test Results And I(d) Structures Of Short-Term Real Interest Rates.

\begin{tabular}{|c|c|c|c|c|c|}
\hline & \multicolumn{2}{|c|}{$\begin{array}{c}\text { ADF Test (Probabilities) } \\
\text { with levels }\end{array}$} & \multicolumn{2}{|c|}{$\begin{array}{l}\text { ADF Test (Probabilities) } \\
\text { with } 1^{\text {st }} \text { Differences }\end{array}$} & \multirow{2}{*}{$\begin{array}{c}\text { I(d) } \\
\text { Structures }\end{array}$} \\
\hline & $\begin{array}{c}\text { with } \\
\text { intercept }\end{array}$ & $\begin{array}{l}\text { with intercept } \\
\text { and trend }\end{array}$ & $\begin{array}{c}\text { with } \\
\text { intercept }\end{array}$ & $\begin{array}{l}\text { with intercept } \\
\text { and trend }\end{array}$ & \\
\hline Austria & 0.5645 & 0.1513 & $0.0092 *$ & $0.0399 *$ & $\mathrm{I}(1)$ \\
\hline Belgium & $0.0210 *$ & $0.0909 * *$ & $0.0000 *$ & $0.0000 *$ & $\mathrm{I}(0)$ \\
\hline Denmark & 0.5733 & 0.4291 & $0.0000 *$ & $0.0000 *$ & $\mathrm{I}(1)$ \\
\hline Finland & 0.4079 & 0.4662 & $0.0000 *$ & $0.0000 *$ & $\mathrm{I}(1)$ \\
\hline France & 0.1364 & 0.3570 & $0.0000 *$ & $0.0000 *$ & $\mathrm{I}(1)$ \\
\hline Germany & 0.1862 & 0.1332 & $0.0000 *$ & $0.0000 *$ & $\mathrm{I}(1)$ \\
\hline Holland & $0.0000^{*}$ & $0.0000 *$ & $0.0000 *$ & $0.0000 *$ & $\mathrm{I}(0)$ \\
\hline Iceland & 0.3608 & 0.4067 & $0.0000 *$ & $0.0000 *$ & $\mathrm{I}(1)$ \\
\hline Ireland & 0.4850 & 0.6878 & $0.0000 *$ & $0.0000 *$ & $\mathrm{I}(1)$ \\
\hline Italy & 0.7236 & 0.5514 & $0.0000 *$ & $0.0000 *$ & $\mathrm{I}(1)$ \\
\hline Norway & $0.0970^{* *}$ & 0.1360 & $0.0000 *$ & $0.0000 *$ & $\mathrm{I}(1)$ \\
\hline Portugal & $0.0851 * *$ & 0.4789 & $0.0000 *$ & $0.0000 *$ & $\mathrm{I}(1)$ \\
\hline Spain & $0.0067 *$ & $0.0217 *$ & $0.0000^{*}$ & $0.0000 *$ & $\mathrm{I}(0)$ \\
\hline Sweden & 0.3154 & $0.0021 *$ & $0.0000 *$ & $0.0000 *$ & $\mathrm{I}(1)$ \\
\hline Switzerland & $0.0003 *$ & $0.0020^{*}$ & $0.0000 *$ & $0.0000 *$ & $\mathrm{I}(0)$ \\
\hline UK & $0.0190 *$ & $0.0258 *$ & $0.0000 *$ & $0.0000 *$ & $\mathrm{I}(0)$ \\
\hline
\end{tabular}

Reported figures are the MacKinnon (1996) critical values. * implies significance at 5 $\%$ levels. ** implies significance at $10 \%$ levels. 
Cross-Country Interest Rate Trends: The Case of European Countries

Table V: AR(p) Structures.

\begin{tabular}{|l|l|l|l|l|}
\hline & \multicolumn{1}{|c|}{ Long Nominal } & \multicolumn{1}{c|}{ Long Real } & \multicolumn{1}{c|}{ Short Nominal } & \multicolumn{1}{c|}{ Short Real } \\
\hline Austria & 1 & 1,5 & 1 & 3 \\
\hline Belgium & 1 & $1,4,8$ & 1,2 & 1,2 \\
\hline Denmark & $1,4,5$ & $1,5,8$ & 5 & 5 \\
\hline Finland & $1,4,7$ & 1,4 & 3,10 & 2 \\
\hline France & 1 & $1,2,4,8$ & 1,5 & $1,2,5$ \\
\hline Germany & $1,2,5$ & 4 & 1,2 & 4 \\
\hline Holland & $1,2,3,4,9,12$ & 4 & $1,4,6$ & 1,2 \\
\hline Iceland & 1 & 4,5 & 2 & 2 \\
\hline Ireland & 1,5 & $1,2,3,4$ & 1 & - \\
\hline Italy & $1,4,5$ & $1,2,3,5,9$ & 1 & 4 \\
\hline Norway & 1 & 4 & 1 & 4 \\
\hline Portugal & 1 & 1,4 & 2 & 3 \\
\hline Spain & $1,2,5,7$ & 1,4 & $2,3,5,7$ & 1,6 \\
\hline Sweden & 1,4 & 1,4 & $4,6,7,8$ & $4,8,9$ \\
\hline Switzerland & 1,5 & 1,4 & 1,2 & $1,2,10$ \\
\hline UK & 1,2 & 1,5 & 1,9 & 1 \\
\hline
\end{tabular}


Table VI: ADF Test Probability Outputs For Residuals Derived From The Bivariate Long Run Relationship Regressions Of Country Pairs Using Long-Term Nominal Interest Rates.

\begin{tabular}{|c|c|c|c|c|c|c|c|c|}
\hline \multicolumn{9}{|c|}{ Long-Term Nominal Interest Rates } \\
\hline & \multicolumn{8}{|c|}{ Independent Variable Series in the Long Run Relationship Regression } \\
\hline & Austria & Belgium & Denmark & Finland & France & Germany & Holland & Iceland \\
\hline \multicolumn{9}{|l|}{$\begin{array}{l}\text { Dependent } \\
\text { Variable } \\
\text { Series } \\
\end{array}$} \\
\hline Austria & - & $0.0003 *$ & $0.0001^{*}$ & 0.1351 & 0.0566 & $0.0034 *$ & 0.1311 & 0.7052 \\
\hline Belgium & $0.0001 *$ & - & $0.0145^{*}$ & $0.0009^{*}$ & $0.0195^{*}$ & 0.1396 & 0.3844 & 0.5571 \\
\hline Denmark & $0.0000 *$ & $0.0037 *$ & - & $0.0053^{*}$ & $0.0000^{*}$ & $0.0001 *$ & $0.0001 *$ & 0.7759 \\
\hline Finland & 0.0816 & $0.0268 *$ & $0.0103 *$ & - & $0.0003^{*}$ & 0.0613 & $0.0327 *$ & 0.7113 \\
\hline France & $0.0391 *$ & $0.0195^{*}$ & $0.0000^{*}$ & $0.0002 *$ & - & 0.2305 & 0.2423 & 0.7111 \\
\hline Germany & $0.0030 *$ & 0.0619 & $0.0025^{*}$ & 0.1821 & 0.1128 & - & 0.1773 & 0.7123 \\
\hline Holland & 0.1053 & 0.2806 & $0.0121 *$ & $0.0380^{*}$ & 0.0673 & 0.2558 & - & 0.6694 \\
\hline Iceland & $0.0481 *$ & $0.0499^{*}$ & 0.0575 & 0.0598 & 0.0531 & 0.0529 & 0.0502 & - \\
\hline Ireland & 0.6493 & 0.1051 & 0.1734 & 0.2878 & $0.0016^{*}$ & 0.3011 & 0.1832 & 0.5680 \\
\hline Italy & 0.2712 & $0.0042 *$ & 0.1320 & 0.4021 & 0.1700 & 0.6101 & 0.2184 & 0.6572 \\
\hline Norway & $0.0033^{*}$ & 0.1877 & 0.0537 & $0.0000^{*}$ & 0.0673 & 0.1131 & 0.0918 & 0.6925 \\
\hline Portugal & 0.2569 & 0.0701 & $0.0303^{*}$ & $0.0279^{*}$ & 0.0550 & 0.1155 & 0.0591 & 0.6334 \\
\hline Spain & $0.0085^{*}$ & $0.0314 *$ & $0.0000 *$ & $0.0071^{*}$ & 0.2277 & 0.0683 & 0.1446 & 0.6975 \\
\hline Sweden & $0.0107 *$ & $0.0093 *$ & $0.0011^{*}$ & 0.1298 & $0.0057^{*}$ & $0.0091 *$ & $0.0065^{*}$ & 0.8005 \\
\hline Switzerland & $0.0195^{*}$ & 0.0989 & $0.0499^{*}$ & $0.0078^{*}$ & 0.0928 & $0.0037 *$ & 0.1042 & 0.0881 \\
\hline \multirow[t]{3}{*}{ UK } & $0.0041 *$ & 0.0589 & $0.0204 *$ & $0.0121^{*}$ & $0.0225^{*}$ & 0.1183 & $0.0033^{*}$ & 0.3785 \\
\hline & \multicolumn{8}{|c|}{ Independent Variable Series in the Long Run Relationship Regression } \\
\hline & Ireland & Italy & Norway & Portugal & Spain & Sweden & Switzerland & UK \\
\hline \multicolumn{9}{|l|}{$\begin{array}{l}\text { Dependent } \\
\text { Variable } \\
\text { Series } \\
\end{array}$} \\
\hline Austria & 0.7807 & 0.2482 & $0.0098^{*}$ & 0.2871 & $0.0132 *$ & $0.0292 *$ & $0.0289^{*}$ & $0.0226^{*}$ \\
\hline Belgium & 0.1569 & $0.0023 *$ & 0.1075 & 0.0508 & $0.0356^{*}$ & $0.0157 *$ & 0.4662 & 0.0935 \\
\hline Denmark & 0.2667 & 0.1018 & 0.2089 & $0.0388^{*}$ & $0.0000^{*}$ & $0.0005^{*}$ & $0.0070^{*}$ & $0.0060 *$ \\
\hline Finland & 0.2983 & 0.3792 & $0.0022 *$ & $0.0271^{*}$ & $0.0060^{*}$ & 0.1339 & $0.0075^{*}$ & $0.0110^{*}$ \\
\hline France & $0.0024 *$ & 0.1246 & $0.0252^{*}$ & 0.0916 & 0.2068 & $0.0035^{*}$ & 0.5337 & $0.0365^{*}$ \\
\hline Germany & 0.1333 & 0.2100 & 0.1852 & 0.1241 & 0.0664 & $0.0215^{*}$ & $0.0112^{*}$ & 0.0767 \\
\hline Holland & $0.0278 *$ & 0.1431 & 0.0999 & 0.0617 & 0.0896 & $0.0103 *$ & 0.3696 & $0.0034 *$ \\
\hline Iceland & 0.0544 & 0.0571 & 0.0576 & 0.0574 & 0.0574 & 0.0645 & $0.0420^{*}$ & 0.0627 \\
\hline Ireland & - & $0.0179^{*}$ & $0.0303 *$ & 0.0746 & $0.0340^{*}$ & $0.0002 *$ & 0.4822 & 0.0940 \\
\hline Italy & $0.0252 *$ & - & 0.3766 & $0.0116^{*}$ & $0.0058^{*}$ & $0.0227^{*}$ & $0.0235^{*}$ & 0.3602 \\
\hline Norway & 0.4219 & 0.2006 & - & 0.2843 & 0.0860 & $0.0129 *$ & 0.4641 & 0.1766 \\
\hline Portugal & 0.0685 & $0.0091^{*}$ & 0.1541 & - & $0.0054 *$ & $0.0225^{*}$ & $0.0467 *$ & $0.0485 *$ \\
\hline Spain & 0.1451 & $0.0056^{*}$ & 0.0780 & $0.0067 *$ & - & $0.0003 *$ & 0.1010 & $0.0053 *$ \\
\hline Sweden & $0.0019 *$ & $0.0357^{*}$ & 0.1577 & $0.0274 *$ & $0.0002 *$ & - & $0.0318^{*}$ & $0.0036^{*}$ \\
\hline Switzerland & 0.1225 & $0.0096^{*}$ & 0.3196 & $0.0210^{*}$ & $0.0496^{*}$ & $0.0410 *$ & - & 0.0609 \\
\hline UK & 0.1067 & 0.5594 & 0.1877 & 0.0731 & $0.0002^{*}$ & $0.0067 *$ & 0.4799 & - \\
\hline
\end{tabular}

Reported figures are the MacKinnon (1996) critical values. * implies significance at $5 \%$ levels. 
Table VII: ADF Test Probability Outputs For Residuals Derived From The Bivariate Long Run Relationship Regressions Of Country Pairs Using Long-Term Real Interest Rates.

\begin{tabular}{|c|c|c|c|c|c|c|c|c|}
\hline \multicolumn{9}{|c|}{ Long-Term Real Interest Rates } \\
\hline & \multicolumn{8}{|c|}{ Independent Variable Series in the Long Run Relationship Regression } \\
\hline & Austria & Belgium & Denmark & Finland & France & Germany & Holland & Iceland \\
\hline \multicolumn{9}{|l|}{$\begin{array}{l}\text { Dependent } \\
\text { Variable } \\
\text { Series } \\
\end{array}$} \\
\hline Austria & - & NA & NA & NA & NA & NA & NA & NA \\
\hline Belgium & NA & - & $0.0013 *$ & 0.1360 & $0.0052^{*}$ & $0.0021 *$ & $0.0271 *$ & 0.1573 \\
\hline Denmark & NA & $0.0125^{*}$ & - & $0.0104 *$ & $0.0302^{*}$ & 0.0845 & $0.0483^{*}$ & 0.8226 \\
\hline Finland & NA & 0.1429 & $0.0110^{*}$ & - & $0.0227 *$ & 0.0727 & 0.1360 & 0.5045 \\
\hline France & NA & $0.0011 *$ & $0.0120 *$ & 0.2554 & - & $0.0136^{*}$ & 0.2128 & 0.0918 \\
\hline Germany & NA & $0.0217 *$ & 0.1059 & 0.0824 & 0.0558 & - & 0.2254 & 0.2991 \\
\hline Holland & NA & 0.1125 & 0.0578 & 0.4732 & 0.0671 & $0.0322 *$ & - & 0.8529 \\
\hline Iceland & NA & 0.1222 & 0.7626 & 0.1065 & $0.0092^{*}$ & 0.5638 & 0.0925 & - \\
\hline Ireland & NA & 0.0898 & $0.0064 *$ & 0.4344 & 0.0636 & $0.0000 *$ & 0.0854 & 0.8751 \\
\hline Italy & NA & NA & $\mathrm{NA}$ & $\mathrm{NA}$ & NA & $\mathrm{NA}$ & NA & NA \\
\hline Norway & NA & 0.0653 & $0.0050^{*}$ & $0.0076^{*}$ & 0.0512 & $0.0392 *$ & 0.0554 & 0.1304 \\
\hline Portugal & NA & 0.1731 & 0.1198 & 0.5709 & 0.3083 & 0.1982 & 0.5060 & 0.2685 \\
\hline Spain & NA & $0.0005^{*}$ & 0.0750 & 0.1290 & $0.0000 *$ & 0.3106 & 0.1391 & 0.3308 \\
\hline Sweden & NA & 0.3609 & 0.1884 & 0.4027 & 0.2817 & $0.0400 *$ & $0.0362 *$ & 0.6237 \\
\hline Switzerland & NA & $0.0024 *$ & 0.2136 & 0.2639 & $0.0034 *$ & $0.0000 *$ & $0.0001^{*}$ & $0.0020^{*}$ \\
\hline \multirow[t]{3}{*}{ UK } & NA & NA & NA & NA & $\mathrm{NA}$ & NA & NA & NA \\
\hline & \multicolumn{8}{|c|}{ Independent Variable Series in the Long Run Relationship Regression } \\
\hline & Ireland & Italy & Norway & Portugal & Spain & Sweden & Switzerland & UK \\
\hline \multicolumn{9}{|l|}{$\begin{array}{l}\text { Dependent } \\
\text { Variable } \\
\text { Series } \\
\end{array}$} \\
\hline Austria & NA & NA & NA & NA & NA & NA & NA & NA \\
\hline Belgium & $0.0015^{*}$ & NA & 0.2192 & 0.1287 & $0.0025^{*}$ & 0.4333 & 0.0523 & NA \\
\hline Denmark & 0.0674 & NA & 0.4261 & 0.4510 & 0.0831 & 0.7620 & 0.2814 & NA \\
\hline Finland & 0.2221 & NA & 0.0574 & 0.5370 & 0.3072 & 0.5982 & 0.5635 & NA \\
\hline France & $0.0471 *$ & NA & 0.2192 & 0.2748 & $0.0000^{*}$ & 0.4348 & 0.3144 & NA \\
\hline Germany & 0.1121 & NA & 0.1362 & 0.1123 & 0.1128 & $0.0469^{*}$ & $0.0283^{*}$ & NA \\
\hline Holland & 0.1447 & NA & 0.5945 & 0.8786 & 0.1672 & $0.0307 *$ & 0.0542 & NA \\
\hline Iceland & 0.3959 & NA & 0.1828 & 0.3075 & $0.0203^{*}$ & 0.2656 & 0.0780 & NA \\
\hline Ireland & - & NA & 0.4862 & 0.3794 & 0.1051 & 0.0738 & 0.2140 & NA \\
\hline Italy & NA & - & NA & NA & NA & NA & NA & NA \\
\hline Norway & $0.0075^{*}$ & NA & - & 0.0662 & $0.0100 *$ & 0.6066 & 0.1188 & NA \\
\hline Portugal & 0.3872 & NA & 0.1919 & - & 0.1605 & 0.6715 & 0.0995 & NA \\
\hline Spain & 0.0758 & NA & $0.0472 *$ & 0.4911 & - & 0.6061 & 0.4595 & NA \\
\hline Sweden & $0.0035^{*}$ & NA & 0.2805 & 0.9641 & 0.3094 & - & $0.0407 *$ & NA \\
\hline Switzerland & $0.0001 *$ & NA & $0.0003^{*}$ & $0.0003^{*}$ & $0.0015^{*}$ & $0.0123 *$ & - & NA \\
\hline UK & NA & NA & NA & NA & NA & NA & NA & - \\
\hline
\end{tabular}

Reported figures are the MacKinnon (1996) critical values. * implies significance at $5 \%$ levels. NA states that $\mathrm{ADF}$ unit root test was not applied to series due to the series being $\mathrm{I}(0)$. 
Table VIII: ADF Test Probability Outputs For Residuals Derived From The Bivariate Long Run Relationship Regressions Of Country Pairs Using Short-Term Nominal Interest Rates.

\begin{tabular}{|c|c|c|c|c|c|c|c|c|}
\hline \multicolumn{9}{|c|}{ Short-Term Nominal Interest Rates } \\
\hline & \multicolumn{8}{|c|}{ Independent Variable Series in the Long Run Relationship Regression } \\
\hline & Austria & Belgium & Denmark & Finland & France & Germany & Holland & Iceland \\
\hline \multicolumn{9}{|l|}{$\begin{array}{l}\text { Dependent } \\
\text { Variable } \\
\text { Series } \\
\end{array}$} \\
\hline Austria & - & $0.0042 *$ & $0.0024 *$ & $0.0335^{*}$ & $0.0034 *$ & NA & NA & $0.0001^{*}$ \\
\hline Belgium & $0.0030 *$ & - & $0.0002 *$ & $0.0115^{*}$ & $0.0000 *$ & $\mathrm{NA}$ & NA & $0.0000^{*}$ \\
\hline Denmark & $0.0012 *$ & $0.0001 *$ & - & $0.0011^{*}$ & $0.0001 *$ & NA & NA & $0.0000^{*}$ \\
\hline Finland & $0.0138 *$ & $0.0071^{*}$ & $0.0017 *$ & - & $0.0002 *$ & NA & NA & 0.0617 \\
\hline France & $0.0021 *$ & $0.0000^{*}$ & $0.0002 *$ & $0.0003^{*}$ & - & NA & NA & $0.0000^{*}$ \\
\hline Germany & NA & NA & NA & NA & NA & - & NA & NA \\
\hline Holland & NA & NA & NA & NA & NA & NA & - & NA \\
\hline Iceland & $0.0000 *$ & $0.0000^{*}$ & $0.0000^{*}$ & $0.0000^{*}$ & $0.0000^{*}$ & NA & NA & - \\
\hline Ireland & 0.3794 & 0.0791 & $0.0226^{*}$ & 0.4492 & $0.0016^{*}$ & $\mathrm{NA}$ & NA & $0.0000^{*}$ \\
\hline Italy & $0.0039 *$ & $0.0001 *$ & $0.0116^{*}$ & 0.0540 & $0.0308^{*}$ & NA & NA & $0.0023^{*}$ \\
\hline Norway & $0.0142 *$ & 0.1669 & $0.0396^{*}$ & $0.0421 *$ & 0.0986 & NA & NA & $0.0350 *$ \\
\hline Portugal & 0.5219 & 0.1625 & $0.0310^{*}$ & $0.0262 *$ & $0.0331 *$ & NA & NA & $0.0005^{*}$ \\
\hline Spain & 0.0991 & $0.0001 *$ & $0.0041^{*}$ & $0.0161 *$ & $0.0000 *$ & $\mathrm{NA}$ & NA & $0.0192 *$ \\
\hline Sweden & 0.0599 & $0.0013 *$ & $0.0016^{*}$ & 0.2601 & $0.0008^{*}$ & $\mathrm{NA}$ & NA & $0.0000^{*}$ \\
\hline Switzerland & NA & NA & NA & NA & NA & NA & NA & NA \\
\hline \multirow[t]{3}{*}{ UK } & 0.0634 & $0.0327 *$ & 0.2826 & 0.3785 & $0.0326^{*}$ & $\mathrm{NA}$ & $\mathrm{NA}$ & $0.0204 *$ \\
\hline & \multicolumn{8}{|c|}{ Independent Variable Series in the Long Run Relationship Regression } \\
\hline & Ireland & Italy & Norway & Portugal & Spain & Sweden & Switzerland & UK \\
\hline \multicolumn{9}{|l|}{$\begin{array}{l}\text { Dependent } \\
\text { Variable } \\
\text { Series } \\
\end{array}$} \\
\hline Austria & 0.3002 & $0.0034 *$ & 0.1413 & 0.1757 & 0.0904 & 0.0978 & NA & 0.2308 \\
\hline Belgium & 0.0576 & $0.0000^{*}$ & 0.1699 & 0.1122 & $0.0003^{*}$ & $0.0002 *$ & NA & $0.0290^{*}$ \\
\hline Denmark & $0.0115^{*}$ & $0.0033^{*}$ & 0.2351 & $0.0464 *$ & $0.0008^{*}$ & $0.0008^{*}$ & NA & 0.1243 \\
\hline Finland & 0.3497 & $0.0229 *$ & 0.1219 & $0.0021^{*}$ & $0.0129 *$ & 0.1993 & NA & 0.2359 \\
\hline France & $0.0012 *$ & $0.0190 *$ & 0.1035 & $0.0131^{*}$ & $0.0000 *$ & $0.0002 *$ & NA & $0.0255^{*}$ \\
\hline Germany & NA & NA & NA & NA & NA & NA & NA & NA \\
\hline Holland & NA & NA & NA & $\mathrm{NA}$ & NA & NA & NA & $\mathrm{NA}$ \\
\hline Iceland & $0.0000 *$ & $0.0001 *$ & 0.0645 & $0.0000^{*}$ & $0.0000 *$ & $0.0000 *$ & NA & $0.0011 *$ \\
\hline Ireland & - & 0.1383 & 0.2259 & $0.0480 *$ & $0.0056^{*}$ & $0.0052 *$ & NA & 0.3129 \\
\hline Italy & 0.2098 & - & 0.2618 & 0.1889 & 0.1140 & 0.1089 & NA & $0.0106^{*}$ \\
\hline Norway & 0.1752 & 0.0900 & - & $0.0431^{*}$ & $0.0005^{*}$ & 0.1195 & NA & $0.0489^{*}$ \\
\hline Portugal & $0.0015^{*}$ & 0.5345 & 0.1843 & - & $0.0000 *$ & $0.0026^{*}$ & NA & 0.5181 \\
\hline Spain & $0.0027 *$ & 0.0978 & $0.0003^{*}$ & $0.0000^{*}$ & - & $0.0003^{*}$ & NA & $0.0024 *$ \\
\hline Sweden & $0.0105^{*}$ & 0.0605 & 0.1421 & $0.0014 *$ & $0.0004 *$ & - & NA & $0.0013^{*}$ \\
\hline Switzerland & NA & NA & NA & NA & NA & NA & - & NA \\
\hline UK & 0.2632 & $0.0182 *$ & $0.0120 *$ & 0.1994 & $0.0054 *$ & $0.0004 *$ & NA & - \\
\hline
\end{tabular}

Reported figures are the MacKinnon (1996) critical values. * implies significance at $5 \%$ levels. NA states that $\mathrm{ADF}$ unit root test was not applied to series due to the series being $\mathrm{I}(0)$ 
Table IX: ADF Test Probability Outputs For Residuals Derived From The Bivariate Long Run Relationship Regressions Of Country Pairs Using Short-Term Real Interest Rates.

\begin{tabular}{|c|c|c|c|c|c|c|c|c|}
\hline \multicolumn{9}{|c|}{ Short-Term Real Interest Rates } \\
\hline & \multicolumn{8}{|c|}{ Independent Variable Series in the Long Run Relationship Regression } \\
\hline & Austria & Belgium & Denmark & Finland & France & Germany & Holland & Iceland \\
\hline \multicolumn{9}{|l|}{$\begin{array}{l}\text { Dependent } \\
\text { Variable } \\
\text { Series } \\
\end{array}$} \\
\hline Austria & - & NA & $0.0237 *$ & 0.1105 & $0.0269 *$ & $0.0002 *$ & NA & 0.2289 \\
\hline Belgium & NA & - & NA & NA & NA & NA & NA & NA \\
\hline Denmark & $0.0322 *$ & NA & - & $0.0009^{*}$ & $0.0075^{*}$ & $0.0315^{*}$ & NA & 0.1739 \\
\hline Finland & 0.1150 & NA & $0.0006^{*}$ & - & $0.0038^{*}$ & 0.0620 & NA & $0.0193 *$ \\
\hline France & $0.0306^{*}$ & NA & $0.0097 *$ & $0.0077^{*}$ & - & $0.0040^{*}$ & NA & 0.1012 \\
\hline Germany & $0.0004 *$ & NA & $0.0147 *$ & 0.0845 & $0.0020^{*}$ & - & NA & 0.3757 \\
\hline Holland & NA & NA & NA & NA & NA & NA & - & NA \\
\hline Iceland & 0.0704 & NA & $0.0258^{*}$ & $0.0034 *$ & $0.0113^{*}$ & 0.1808 & NA & - \\
\hline Ireland & 0.2390 & NA & $0.0167 *$ & 0.2093 & $0.0006^{*}$ & 0.2045 & NA & $0.0219^{*}$ \\
\hline Italy & $0.0463 *$ & NA & $0.0096^{*}$ & 0.2056 & $0.0375^{*}$ & 0.0691 & NA & 0.1510 \\
\hline Norway & $0.0033^{*}$ & NA & $0.0059^{*}$ & $0.0064 *$ & $0.0009^{*}$ & $0.0000^{*}$ & NA & 0.1181 \\
\hline Portugal & 0.1916 & NA & $0.0217 *$ & 0.6308 & $0.0125^{*}$ & 0.0893 & NA & $0.0064^{*}$ \\
\hline Spain & NA & NA & NA & NA & NA & NA & NA & NA \\
\hline Sweden & 0.3041 & NA & 0.1577 & 0.3090 & 0.0507 & 0.1063 & NA & $0.0013^{*}$ \\
\hline Switzerland & NA & NA & NA & NA & NA & NA & NA & NA \\
\hline \multirow[t]{3}{*}{ UK } & NA & NA & NA & NA & $\mathrm{NA}$ & NA & $\mathrm{NA}$ & NA \\
\hline & \multicolumn{8}{|c|}{ Independent Variable Series in the Long Run Relationship Regression } \\
\hline & Ireland & Italy & Norway & Portugal & Spain & Sweden & Switzerland & UK \\
\hline \multicolumn{9}{|l|}{$\begin{array}{l}\text { Dependent } \\
\text { Variable } \\
\text { Series } \\
\end{array}$} \\
\hline Austria & 0.2219 & 0.1226 & $0.0117 *$ & 0.1193 & NA & 0.1535 & NA & NA \\
\hline Belgium & NA & NA & $\mathrm{NA}$ & NA & NA & NA & NA & NA \\
\hline Denmark & $0.0217 *$ & $0.0129 *$ & $0.0174 *$ & 0.1642 & NA & 0.1250 & NA & NA \\
\hline Finland & 0.1732 & 0.1520 & $0.0122 *$ & 0.1092 & NA & 0.3635 & NA & NA \\
\hline France & $0.0001 *$ & $0.0317 *$ & $0.0007 *$ & $0.0217 *$ & NA & $0.0363 *$ & NA & NA \\
\hline Germany & 0.0588 & 0.0858 & $0.0087 *$ & 0.0958 & NA & 0.1197 & NA & NA \\
\hline Holland & NA & NA & NA & NA & NA & NA & NA & NA \\
\hline Iceland & $0.0222 *$ & $0.0121 *$ & $0.0247 *$ & $0.0001 *$ & NA & $0.0126 *$ & NA & NA \\
\hline Ireland & - & 0.0599 & $0.0445^{*}$ & $0.0089^{*}$ & NA & $0.0072 *$ & NA & NA \\
\hline Italy & 0.1412 & - & 0.0571 & 0.2177 & NA & 0.5365 & NA & NA \\
\hline Norway & $0.0087 *$ & $0.0093 *$ & - & 0.0918 & NA & $0.0328 *$ & NA & NA \\
\hline Portugal & $0.0018 *$ & 0.2151 & 0.1773 & - & NA & $0.0294 *$ & NA & NA \\
\hline Spain & NA & NA & NA & NA & - & NA & NA & NA \\
\hline Sweden & $0.0102 *$ & 0.2715 & $0.0028 *$ & $0.0272 *$ & NA & - & NA & NA \\
\hline Switzerland & NA & NA & NA & NA & NA & NA & - & NA \\
\hline UK & NA & NA & NA & NA & NA & NA & NA & - \\
\hline
\end{tabular}

Reported figures are the MacKinnon (1996) critical values. * implies significance at $5 \%$ levels. NA states that $\mathrm{ADF}$ unit root test was not applied to series due to the series being $\mathrm{I}(0)$. 
Table X: Results Of Serial Common Feature Test.

\begin{tabular}{|l|l|l|}
\hline \multicolumn{2}{|l|}{ Long-term real interest rate } & $\mathrm{CF}=0$ \\
\hline Austria & 1,5 & $21.016^{*}$ \\
\hline UK & 1,5 & \\
\hline Short-term nominal interest rates \\
\hline \multicolumn{2}{|l|}{} \\
\hline Germany & 1,2 & $\mathrm{CF}=0$ \\
\hline Switzerland & 1,2 & $115.647^{*}$ \\
\hline Short-term real interest rates & \\
\hline \multicolumn{2}{|l|}{} \\
\hline Belgium & 1,2 & $\mathrm{CF}=0$ \\
\hline Holland & 1,2 & $222.15^{*}$ \\
\hline
\end{tabular}

* implies the significance of the $\mathrm{F}$ statistics at $5 \%$ level.

\section{REFERENCES}

BREMNES, H., Gjerde, O., Saettem, F. (1997), "A Multivariate Cointegration Analysis of Interest Rates in the Eurocurrency Market" Journal of International Money and Finance, 16(5), pp. 767-778.

DEGRAUWE, P. (1989), “Is the European Monetary System a DM-Zone?”, Centre for Economic Policy Research Working Paper, London.

DEVINE, M. (1997), "The Cointegration of International Interest rates," Central Bank \& Financial Services Authority of Ireland (CBFSAI) Research Technical Papers.

ENGLE, R. F. and Kozicki, S. (1993),'Testing for Common Features", Journal of Business \& Economic Statistics, 11, pp. 369-380.

KIRCHGASSNER, G. and Wolters, J. (1995), "Interest Rate Linkages in Europe Before and After the Introduction of the European Monetary System”, Empirical Economics, 20, pp. 435-54.

LINDENBERG, N. and Westermann, F. (2009), "Common Trends and Common Cycles among Interest Rates of the G7-Countries," CESifo Working Paper Series, CESifo Group Munich.

POGHOSYAN, T. and de Haan, J. (2007), "Interest Rate Linkages in EMU Countries: A Rolling Threshold Vector Error-Correction Approach," CESifo Working Paper Series, CESifo Group Munich.

THORNTON, J. and García-Herrero, A. (1997), "Additional Evidence on Monetary Base and Interest Rate Linkages in the EMS," Review of World Economics, 133(2), pp. 359-368. 
THROOP, A.W. (1994), "International Financial Market Integration and Linkages of National Interest rates”, Federal Reserve Bank of San Francisco Quarterly Review, 3.

ZHOU, S. (2003),"Interest Rate Linkages within the European Monetary System: New Evidence Incorporating Long-Run Trends", Journal of International Money and Finance, 22(4), pp. 571-590. 